\title{
Seating Achievement in Larger University Libraries
}

\begin{abstract}
A questionnaire was sent to the thirty-six largest university libraries in the country inquiring as to their current ability to seat their students. Thirty-two replied. They indicate that the larger libraries, as well as those in private universities, were generally able to seat larger proportions of their students than were smaller libraries and those in state institutions. Plans indicate that these averages will be considerably improved by the year 1970 .
\end{abstract}

$\mathrm{T}$

HE STANDARDS for seating in academic libraries are generally well known. The most familiar of these, developed by the Association of College and Research Libraries, recommends reader stations for at least one-third of the student body in colleges and universities granting the bachelor's and master's degrees.

There is a dearth of inclusive and current information, however, with respect to actual percentages of library seating maintained among types of academic institutions, although such information would be extremely helpful for planning purposes. The most recent general statistics available are for 1957 and provide seating ratios derived from reports from institutions in the United States representing 95.7 per cent of the enrollment in higher education. These reports showed average seating percentages for the fall 1957 enrollment to be as indicated in Table $1 .^{1}$

It is apparent from these figures that,

${ }^{1}$ U.S. Department of Health, Education, and Welfare; Office of Education, College and University Facilities Survey; Part 3: Inventory of College and University Physical Facilities (OE-51007, 1965), p. 389 .

Mr. White is Director for Public Service Departments, University of Illinois Library, Urbana. as of ten years ago, academic libraries in every category fell considerably short, on the average, of meeting generally recognized standards of seating. Whether the over-all average has improved in the last ten years is difficult to determine in the absence of adequate statistical evidence, but the impression of many observers has been that the trend is in the direction of providing reading stations for an increasingly larger proportion of the student population.

Certainly the greatly augmented expenditures on academic library buildings in the last few years would lend strength to that belief. In 1957, for example, only $\$ 20,800,000$ was spent on new library construction and rehabilitation projects

TABLE 1

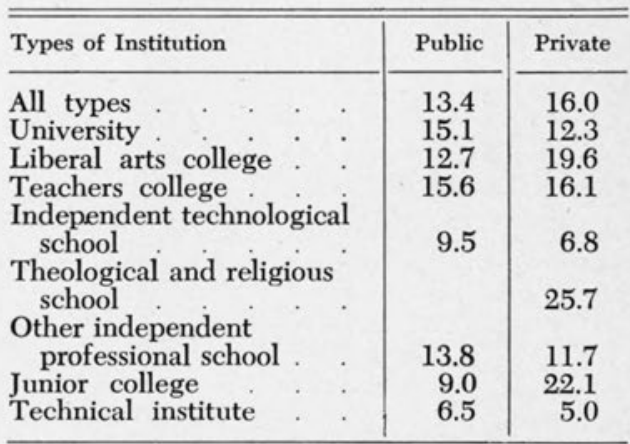


TABLE 2. Seating Statistics for Larger University Libraries

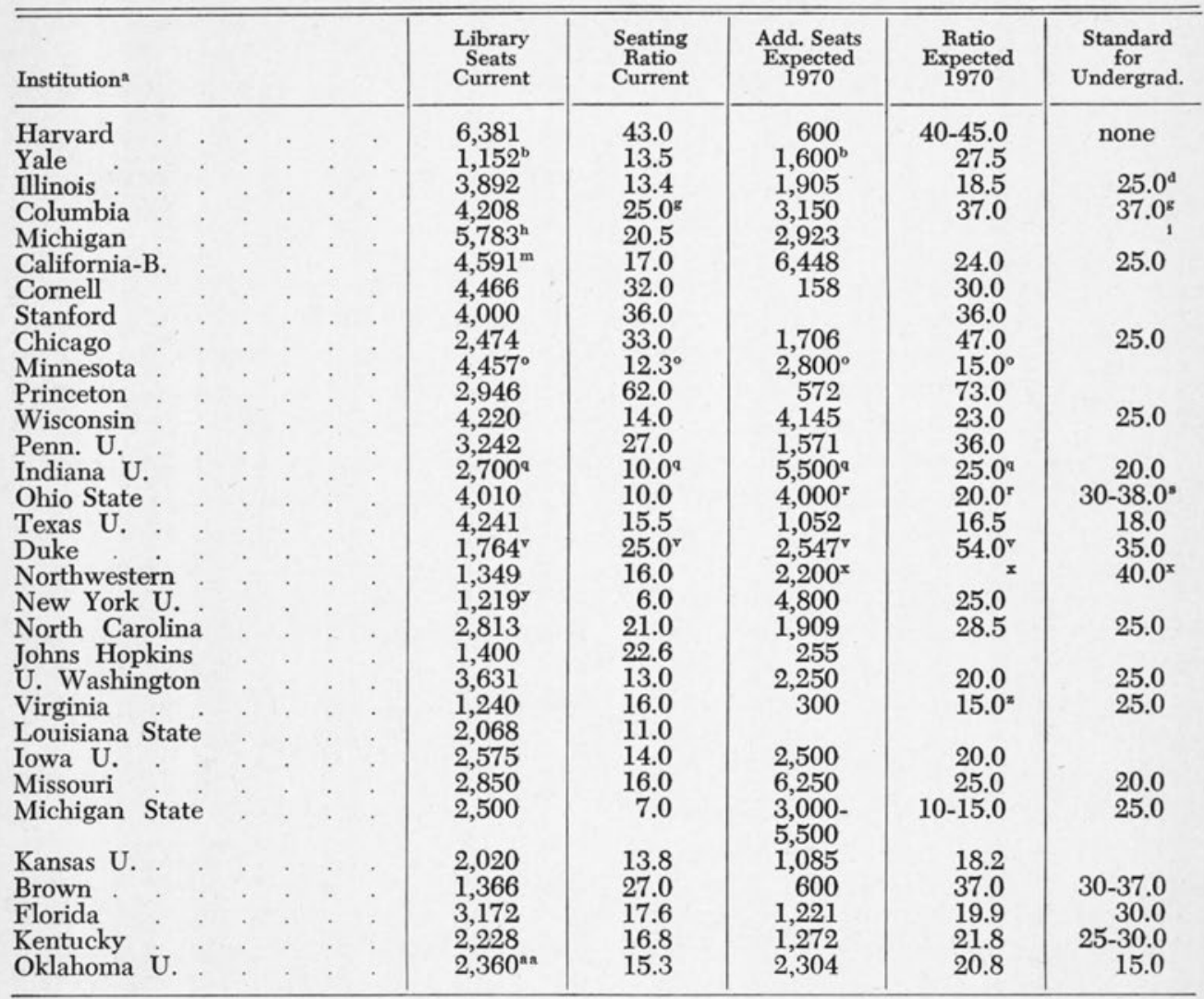

a Arranged by size of book collection.

b Central Building.

c 25 square feet currently provided.

a Includes students in Master's programs.

e 25 per cent standard for doctoral students in areas with high laboratory research demands; 60 per cent standard for doctoral students in areas with low laboratory research demands.

110 per cent standard for faculty with high laboratory research demands; 50 per cent standard for faculty with low laboratory research demands.

$\mathrm{g}$ Does not take into account student readers from affiliated institutions such as Barnard and Teachers College.

h Does not include 5 off-campus libraries.

1 No official standard. Minimum desirable is 25 per cent average. For science students, 15 per cent; for humanities and social science students, 33 per cent.

1 No official standard. Minimum desirable is $\mathbf{5 0}$ per cent average. For science students, 50 per cent; for graduate students in humanities and social sciences would like to provide 100 per cent for those engaged in writing dissertations, 33 per cent for others.

${ }^{k}$ No official standard. Modest standard might be 16 per cent in humanities and social sciences, 4 per cent in sciences.

${ }^{1}$ Includes allowance for aisles.

$m$ Law students and Law Library excluded in all figures.

n No specified standard, but 25 square feet is commonly used in planning.

- Minneapolis and St. Paul campus only.

D In closed one-station carrells.

a Bloomington campus only.

$r$ Estimated.

- For humanities, 30 per cent; for sciences, 33 per cent; for social sciences, 38 per cent.

t For sciences 25-30 per cent; for humanities and social sciences, 45-60 per cent.

u For sciences, 10 per cent; for sciences, 50 per cent; for humanities, 55 per cent.

v Includes Law and Medicine. The Law Library provides seats for 100 per cent of law students and faculty. The Medical Center Library now being planned will seat 100 per cent of its students and most of the faculty.

w Applies to General Library. More space will be allowed in Medical Center and Law Libraries. 
TABLE 2 (Continued)

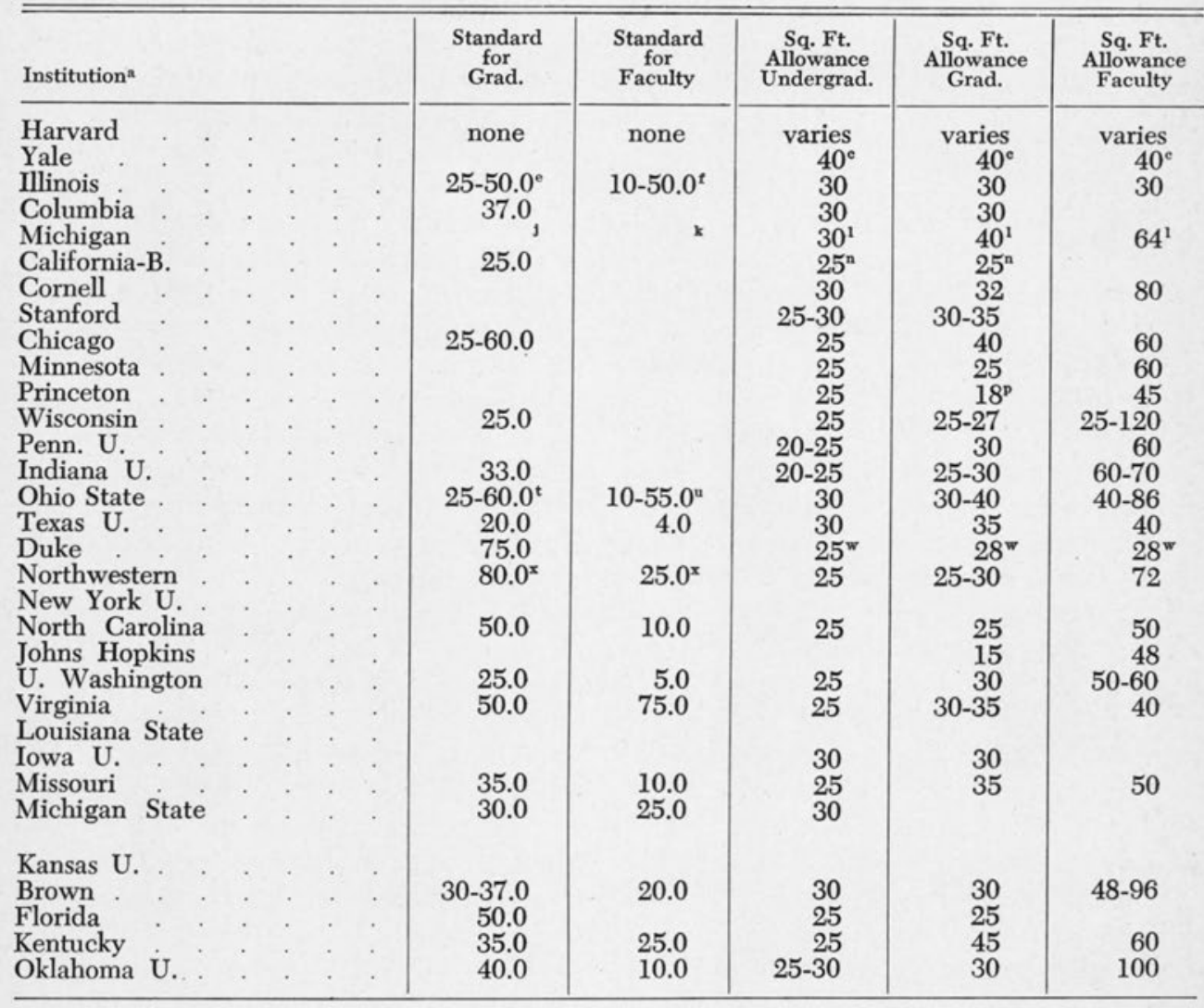

$\times$ Humanities and social sciences only.

y Washington Square only.

z Ratio expected in 1975 is 35.0 .

an Norman campus only.

by all academic institutions. By 1962, the amount spent had risen to $\$ 58,700$,$000 .^{2}$ This increased to $\$ 79,000,000$ spent in 1963 and to $\$ 90,000,000$ spent in 1964 . But the most impressive advances occurred in 1965 and 1966 when expenditures for academic library construction soared to an average of over $\$ 288,000,000$ per year-almost fourteen times the $\$ 20,800,000$ expenditures in $1957 .{ }^{3}$ It would be logical to assume that alloca-

2 Theodore Samore, "Academic Library Buildings: Needs, Legislation, Inventory," College and Research Libraries, XXV (July 1964), 296.

${ }^{3}$ The Bowker Annual of Library and Book Trade Information (New York: R. R. Bowker Co., 1966), p. 32 . tions of these proportions, representing the significant impact of the Higher Education Facilities Act, should eventually have a favorable effect on library seating achievement in spite of increases in enrollment and the factor of inflation.

In order to determine the extent of library seating currently provided or expected in the near future in larger university libraries, the University of Illinois library recently queried the thirtysix university libraries in the United States with book collections of one million or more volumes. The questions covered not only seating ratios but squarefoot allowances per reading station. Since 
the column headings in the accompanying tabulation (Table 2) are necessarily brief, the survey questionnaire is given below for purposes of clarification if needed.

\section{QUESTIONNAIRE}

1. Total number of seats now provided

2. Percentage of student body for which seats are now provided

3. Additional number of seats expected by 1970

4. Percentage of student body for which seats are planned by 1970

5. Percentage figure used as a standard for undergraduate seating

6. Percentage figure used as a standard for graduate seating

7. Percentage figure used as a standard for faculty seating

8. Square feet per reading station allowed for undergraduates

9. Square feet per reading station allowed for graduates

10. Square feet per reading station allowed for faculty

Thirty-two replies were received, and the results are presented in the accompanying tables 2,3 , and 4 . These show that the median seating ratio for the university libraries in this survey is somewhat above the average for all university libraries as reported in the fall 1957 figures. However, those libraries with collections of over two million volumes show a markedly higher median. This seems to result chiefly from the preponderance in that group of private university libraries (seven out of eleven) which have attained higher than average seating ratios, while those libraries with holdings of between one and two million volumes are preponderantly libraries of public universities (fifteen out of twenty-one) which show lower than average seating accomplishment.

The lower seating performance of the public university libraries in this survey is undoubtedly related to the substantially greater enrollment increases absorbed by those institutions in the last decade in comparison with enrollment increases in the private universities. Average full-time enrollment of the public universities in this survey is now 23,648 as opposed to 9,421 for the private universities, and the relative increase in the last decade has been 67 per cent for the public universities as opposed to 22 per cent for the private universities. ${ }^{4}$ On the other hand, the seating needs of the greater numbers of graduate students, proportionately, in the private universities tend to elevate somewhat the seating ratio of the private university libraries, although this factor would be a minor one in assessing the overall difference in performance between types of

Based on comparable statistics of enrollment for 18 public and 13 private universities as reported in School and Society, LXXXV (Dec. 7, 1957), 373-74; XCV (Jan. 7, 1967), 11-12.

TABLE 3. Seating Performance by Type of Library

\begin{tabular}{l|c|c|c|c|c}
\hline \hline & $\begin{array}{c}\text { Median } \\
\text { Seating } \\
\text { Ratio } \\
1966\end{array}$ & $\begin{array}{c}\text { Median } \\
\text { Seating } \\
\text { Ratio } \\
1970\end{array}$ & $\begin{array}{c}\text { Range } \\
1966\end{array}$ & $\begin{array}{c}\text { Range } \\
1970\end{array}$ & $\begin{array}{c}\text { Per cent } \\
\text { Increase of } \\
\text { Seats } \\
\text { Expected } \\
1970\end{array}$ \\
\hline $\begin{array}{l}\text { Libraries over a million volumes } \\
\text { Libraries over two million volumes }\end{array}$ & $16.0^{\mathrm{a}}$ & $25.0^{\mathrm{b}}$ & $6.0-62.0$ & $10.0-73.0$ & $73.8^{\mathrm{a}}$ \\
$\begin{array}{l}\text { Libraries between one and two } \\
\text { million volumes }\end{array}$ & $25.0^{\circ}$ & $30.0^{\mathrm{d}}$ & $12.3-62.0$ & $15.0-73.0$ & $49.3^{\mathrm{e}}$ \\
$\begin{array}{l}\text { Private university libraries } \\
\text { Public university libraries }\end{array}$ & $15.5^{\mathrm{e}}$ & $22.4^{\mathrm{e}}$ & $6.0-27.0$ & $10.0-54.0$ & $94.5^{\mathrm{e}}$ \\
\hline
\end{tabular}

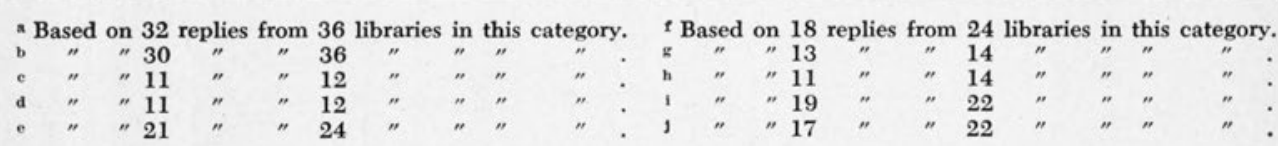


TABLE 4. Seating Standards by Type of Library

\begin{tabular}{lcccccc}
\hline \hline & $\begin{array}{c}\text { Standard } \\
\text { Seating Ratio } \\
\text { for } \\
\text { Undergraduates }\end{array}$ & $\begin{array}{c}\text { Standard } \\
\text { Seating Ratio } \\
\text { for } \\
\text { Graduates }\end{array}$ & $\begin{array}{c}\text { Standard } \\
\text { Seating Ratio } \\
\text { for } \\
\text { Faculty }\end{array}$ & $\begin{array}{c}\text { Square Foot } \\
\text { Allowance } \\
\text { for } \\
\text { Undergraduates }\end{array}$ & $\begin{array}{c}\text { Square Foot } \\
\text { Allowance } \\
\text { for } \\
\text { Graduates }\end{array}$ & $\begin{array}{c}\text { Square Foot } \\
\text { Allowance } \\
\text { for } \\
\text { Faculty }\end{array}$ \\
\hline $\begin{array}{c}\text { Libraries over a } \\
\text { million volumes }\end{array}$ & $27.0^{\mathrm{a}}$ & $40.0^{\mathrm{a}}$ & $22.6^{\mathrm{b}}$ & $27.2^{\mathrm{e}}$ & $30.3^{\mathrm{e}}$ & $56^{\mathrm{d}}$ \\
$\begin{array}{c}\text { Libraries over two } \\
\text { million volumes }\end{array}$ & $.28 .0^{\mathrm{e}}$ & $37.8^{\mathrm{e}}$ & & & & \\
$\begin{array}{c}\text { Libraries between } \\
\text { one and two } \\
\text { million volumes }\end{array}$ & $26.5^{\mathrm{e}}$ & $41.6^{\mathrm{e}}$ & & & & \\
$\begin{array}{c}\text { Private university } \\
\text { libraries . }\end{array}$ & $-34.0^{\mathrm{g}}$ & $53.4^{\mathrm{g}}$ & & & & \\
$\begin{array}{c}\text { Public universities } \\
\text { libraries }\end{array}$ & $24.3^{\mathrm{h}}$ & $35.6^{\mathrm{h}}$ & & & & \\
\hline
\end{tabular}

average based on 19 replies from 36 libraries in this category.

b" " " 12 " " " " " No distinctive variation between types of libraries. e Average square foot allowance based on 27 replies from 36 libraries in this category. No distinctive variation between types of libraries. Represents in many cases individual enclosures without counting aisle space, stairs, etc.

dAverage square foot allowance based on 22 replies from 36 libraries in this category. No distinctive variation between types of libraries. Represents in many cases individual enclosures without counting aisle space, stairs, etc.

- Average based on 4 replies from 12 libraries in this category.

g " " "

h" " 14 " " 22 " "

libraries included in this survey. ${ }^{5}$ Other local factors affecting library seating requirements, such as the nature of the curriculum, quality of the book collection, adequacy of student housing, presence of residence hall libraries, and number of commuting students are all variables which may have a bearing when considering the needs or achievement of individual libraries.

The most optimistic sign arising from this survey is found in the responses to

\footnotetext{
${ }^{5}$ Based on enrollment percentages in Library Statistics of Colleges and Universities, 1963-64; Institutional Data (OE-15023-64), p. 8-59.
}

the questions relating to expected increases in seating accommodations and seating ratios by 1970 . The great majority of libraries expect to make significant advances in seating performance by 1970 , as is illustrated by Table 3 . If these expectations are realized the total number of reading stations in the thirty-two libraries surveyed will increase from 97,318 in 1966 to 169,191 in 1970 , an increase of 73.8 per cent, and the median seating ratio will rise from 16 per cent to 25 per cent, substantially narrowing the gap between seating achievement and seating standards.

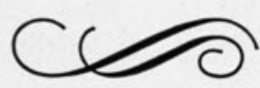

